\title{
微 粒子ケイ酸の塩酸処理†
}

(昭 和 32 年 3 月 23 日 受 理)

平田 好顕*

ケイ酸アルカリを原料とする湿式法微粒子ヶイ酸はアルカリ㑡でつくられる場合が多い。この微粒子ヶイ酸が酸性媒体 に接触した場合の本質的变化を検討する目的で種々の濃度の塩酸に浸漬後, $800^{\circ} \mathrm{C} て ゙$ 熱処理を行い結晶化過程を比較した。 一定時間ことの熱処理試料に一定量の内部標準物質としてコロイド性炭酸カルシウムを混合し，X楾回折図の強度比より 結晶化過程を追跡した。未処理のすのは熱処理を行 万と無定形よりクリストバライトに変化するが，塩酸 $0.1 \%$ 程度の処 理では単にクリストバライトへの結晶化速度が遅くなるが, 塩酸 $0.3 \%$ になるとクリストバライトの結晶化速度が遅くな ると同時に石英が生成し，1\% 濃度において最高の石英生成を示す。さらに濃度か上年し，7\%になると石英のみ生成し， 10\%では結晶の生成を認めない。塩酸ガスの吸着では単に結晶速度が達くなるのみである。塩酸によるケイ酸，不純物 の溶出等の原因が考えられる。

\section{緒 言}

ケイ酸ソーダのよ5なケイ酸アルカリを酸性物質で分解してつ くられる微粒子ケイ酸は中性ないし微アルカリ性の状態で使用さ れているものが多い1)。このような微粒子ケイ酸が製造の際ある いは用途の環境によってさらに酸性媒体に接触することによる変 化過程を知る目的で種々の濃度の塩酸に浸漬処理した試料につい て熱処理を行い, 結晶化状態の変化を比較した。

従来水素イオン濃度による析出相の相違はアルカリ性で石英, 中性または酸性ではクリストバライトが出来るとされている2)。 湿式法でつくられた微粒子ケイ酸は熱処理によってクリストバラ イトを晶出する3)。

本報においては塩酸処理によって無定形ヶイ酸より従来の結果 と異なり石英の生成する結果をえた。酸濃度および酸処理時間と 結晶の晶出状態をX 線回折により究明した。

\section{実験}

a) 試料の調製

湿式法微粒子ケイ 酸は既報9,4) と同一 のものを使用し, 微 粒子ケイ酸 $10 \mathrm{~g}$ を 0.1 ないし $10 \%$ 濃 度の塩酸 $100 \mathrm{cc}$ に 浸漬し, $50^{\circ} \mathrm{C}$ の恒温 水槽中で一定時間放 置後,ただちに吸引 口過し, $200 \mathrm{cc}$ の水 で水洗し $105^{\circ} \mathrm{C}$ で 3 時間乾燥し試料を調 弊した。 $50^{\circ} \mathrm{C}$ の浸 漬試験は常温付近で
第1図クリストバライトならびに 石英の強度比の測定

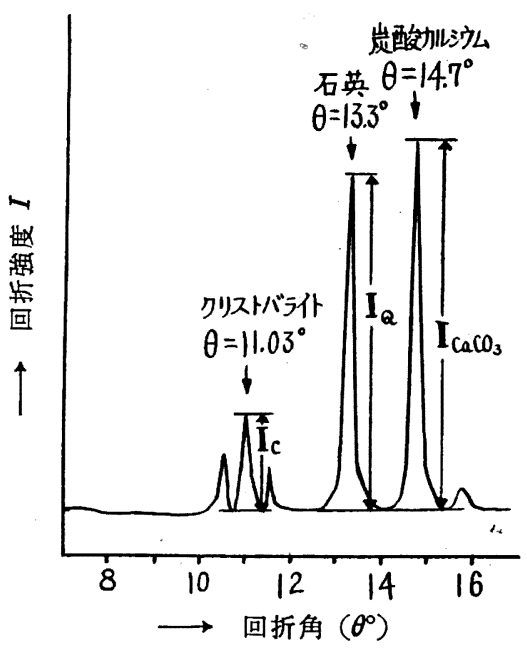

†本報を「微粒子ケイ酸に関する研究（第 3 報）」とする.

* 兵庫県工業橆励館：神戸市須唐区.

1）たとえば Columbia Southern Chemical Corp. 特許公告 昭 31-7275.

2) 桐山, 射場本, 実験化学講座 4, p. 3 ; J. F. Corwin, A. H. Herzog, J. Am. Chem. Soc. 75, 3933 (1953).

3) 平田, 橋詰, 横山, 工化 59,322 (1956).

4) 平田, 橋詰, 工化“59, 1225 (1956).
行 5 と濃度効果を検討するのにきわめて長時間を要するため促進 する目的で行った。

b) 結晶化とその測定 種々の濃度の塩酸処理試料を $800^{\circ} \mathrm{C}$ の電気炉中で熱処理を行い，一定時間ごとに試料を採取し結晶化 状態を測定した。熱処理温度を $800^{\circ} \mathrm{C}$ とたのは塩酸処理を行わ ない場合, 比較的短時間の熱処理でクリストバライトのX線回折 図を示すためである 化の測定は Rich Seifert 社䌘 $\mathrm{Cu} \mathrm{K} \boldsymbol{\alpha}$ 線を使用し, 測定条件は $35 \mathrm{kV}, 7.5 \mathrm{~mA}$ とした。結晶化 過程に执いて試料による回折線の拡がりの差異はほとんど無視出 来る程度であったので, 回折強度を比較するため内部標準物質と してコロイド性炭酸カルシウムを熱処理試料の 2 倍量混合した。

第 2 図クリストバライトならびに石英の生成量の時間的変化 一・ークリストバライト 一メ石 英

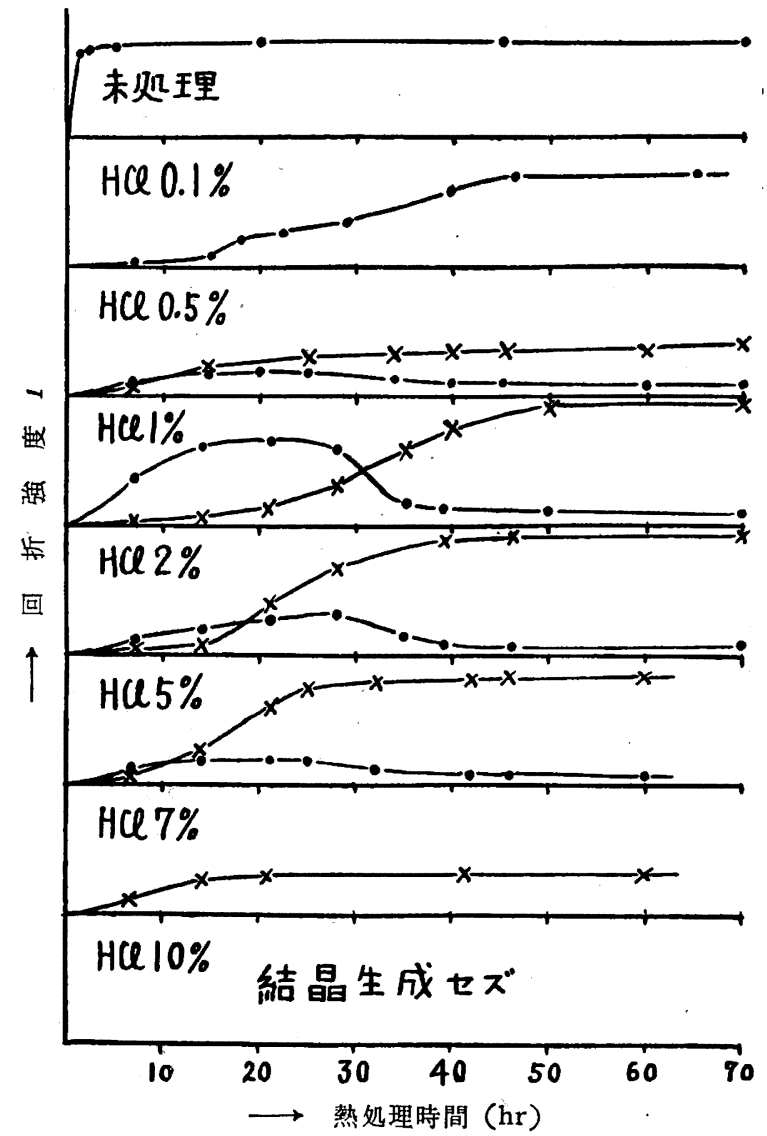


コロイド性炭酸カルシウムは他の軽質炭酸カルシウム, 重質炭酸 カルシウムのように結晶の配向性を示さない5)。また生成したク リストバライト，石英の回折図はそれぞれの強度比に特異性が見 られなかったので結晶の配向現象はないものと考えた。そのため 第1図に示すよ5Kクリストバライト, 石英の生成量をクリスト バライトならびに石英のそれぞれの最強回折線である $\theta=11.03^{\circ}$ と $13.3^{\circ}$ の強度を内部標準物質コロイド性炭酸カルシウムの最強 回折線 $\theta=14.7^{\circ}$ の強度を標準として比較した。

c） 実験結果 種々の濃度の塩酸により 1 時間浸漬した試料に ついてコロイド性炭酸カルシウムを標準としてクリストバライト と石英の生成率の時間的変化を第 2 罒に示した。

第 2 図に拉いて未処理の場合では非常に速くクリストハシライト が生成するが，塩酸 $0.1 \%$ 処理ではクリストバライトの生成速 度が遅くなる。0.5\% になるとクリストバライトの生成量が非常 に少なくなると同時に石英が生成し，結晶質合量は少なくなる。 1\%に上上年すると最初はクリストバライトが多量に生成するが, 石英の生成とともに減少して行く傾向が見られる。2\%，5\%と 類似の傾向であるが，塩酸濃度の上年とともに石英の生成量が平 衡に達するのが速くなり，反対に石英の生成量が平衡に達するの が遅いほど生成量は大である。7\% では石英のみが生成しクリス トハシライトの生成は認められない。10\%まで濃度が高くなると 熱処理を継続しても無定形で結晶の生成は認められない。

以上の結果ではクリストバライトと石英の比較は出来るが無定 形ケイ酸の残存量は明らかでない。クリストバライト，石英，無 定形ケイ酸の間の関係を知る必要がある。まずクリストバライト と石英を定

量するため コロイド性 炭酸カルシ ウムに対す る石英なら びにクリス トバライト のそれぞれ の回折強度 比 $I / I_{\mathrm{CaCO}_{3}}$ と重量比 $W / W_{\mathrm{CaCO}_{3}}$ の関係を求 めた結果を 第 3 図に示 寸。

第3図炭酸カルシウム石英ならびに炭酸カル シウムークリストバライト系の回折強度比 $I / I_{\mathrm{CaCO}_{\mathrm{a}}}$ - 重量比 $W / W \mathrm{CaCO}_{3}$ 関係

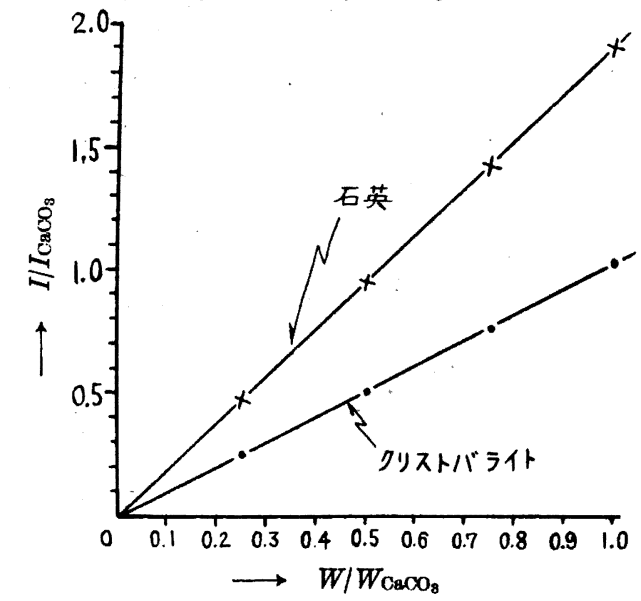

このような検量線を作製する場合，石英，クリストバライトの 標準物質が問題となるが，実際問題として $100 \%$ 結晶したすのは 存在しないから，石英は天然石英粉より特に結晶化度の高く回折 線の拡がりが類似のものを選定し，クリストハラライトは微粒子ヶ イ酸を $1100^{\circ} \mathrm{C} て ゙ 20$ 時間熱処理したものを $100 \%$ と仮定した。 第 3 図より石英とクリストバライトの量を求め, 残量を無定形 ケイ酸とした。このようにして求めた石英, クリストバライト, 無定形ヶイ酸の種々の塩酸処理試料について熱処理変化を第 4 困 に示す。

5) 橋詰, 萩野, 分析化学 5, 207 (1956).
第 4 図塩酸濃度の影很

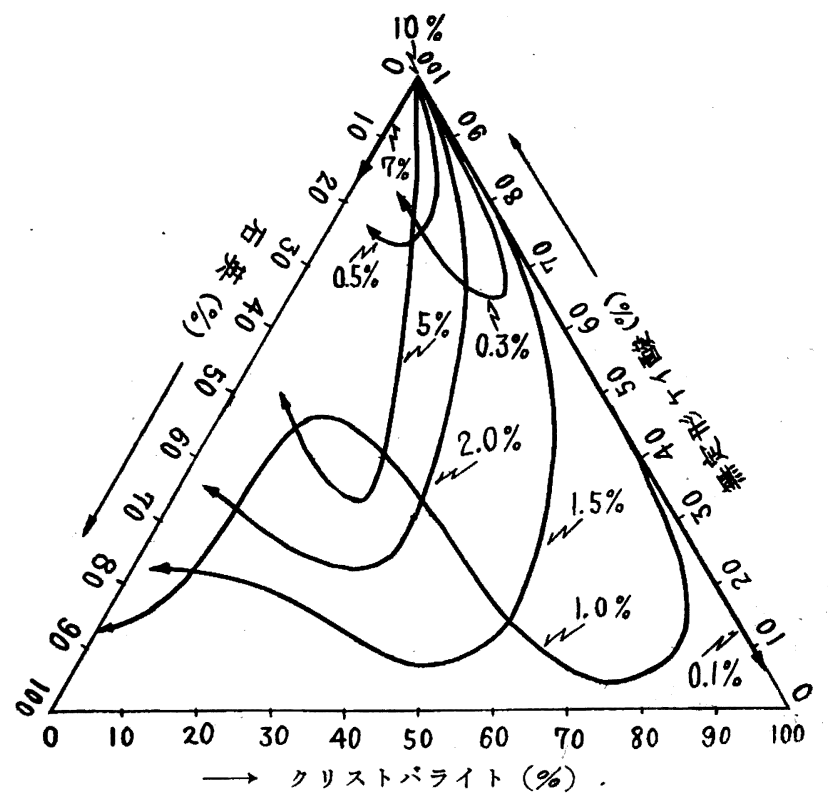

第 4 図では無定形ケイ酸と結晶質であるクリストバライト，石 英との関係が明瞭となり, 塩酸濃度 $0.1 \%$ では結晶量が多く, 塩 酸濃度が上昇すると無定形ケイ酸が多くなるが，再び $1 \%$ の濃度 で結晶量が多くなり石英の生成が最高となる。これ以上濃度が增 加すると無定形ヶイ酸の量が多くなり，10\% の濃度で無定形ヶ イ酸が $100 \%$ となり，熱処理時間によのて変化がない。1\%濃度 に拈ける変化の過程からクリストバライトより石英への变化は直 接転移するものではなく，一度無定形ヶイ酸を経ることが推察さ れる。

以上の結果は浸漬時間を 1 時間に限定した場合であるが，浸漬 時間を変化すると希薄な濃度では短時間の試験ではほとんど差異 が見られなかったが，濃度がある程度高くなると熱処理による変

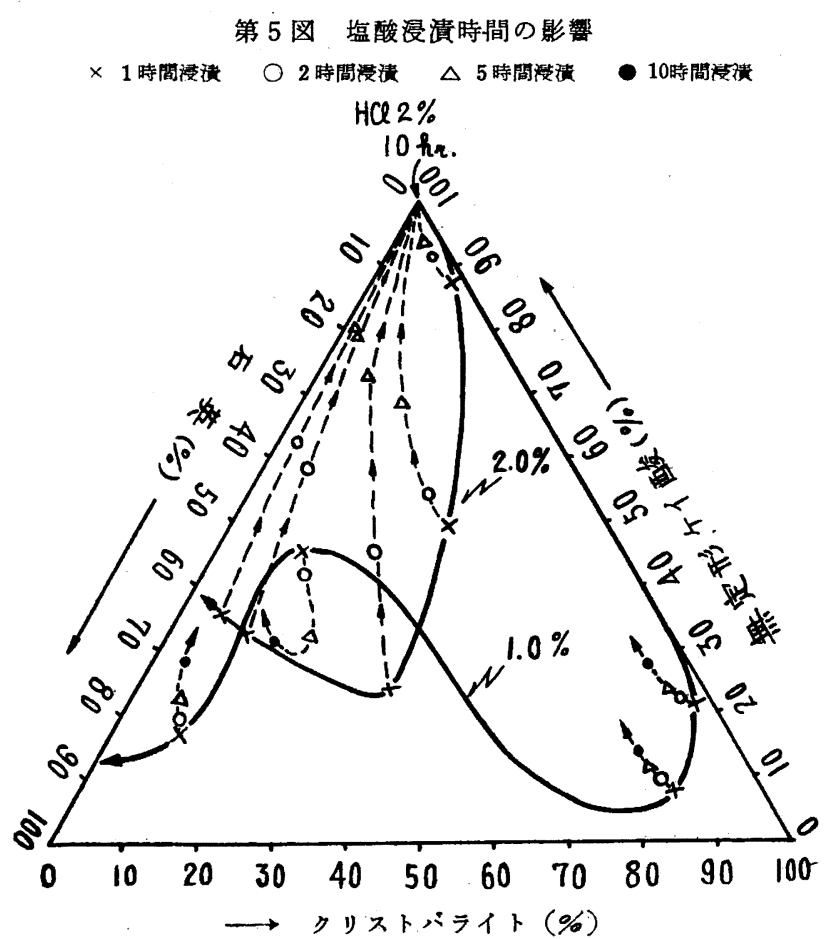


化過程が違って来る。第 5 四にその例を示した。

第 5 図に示した塩酸濃度 $1 \%$ ならびに $2 \%$ の結果より浸漬時 間とともに一般に無定形ケイ酸の方向へ移動し結晶量の減少が見 られる。2\%で 10 時間浸漬すると完全に無定形のまま残り, 結晶 の生成が見られなくなる。無定形のまま残存するすのはさらに熱 処理温度を上年し, $110^{\circ} \mathrm{C}$ に達しても結晶の生成を認めない。

\section{考察}

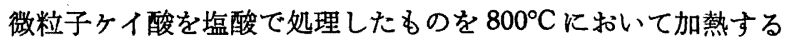
と無定形ケイ酸がクリストバライト，ならびに石英に相転移する が，塩酸濃度が高くなると結晶の生成が少なくなる。また漫潰時 間が長くなると同様に無定形ヶイ酸が多くなる。このような転移 過程の原因について考察を加えるため三,三の補足試験を行った。

1）塩酸ガスによる処理 微粒子ケイ酸表面に塩酸が吸着する ことによってこのような転移が起るならば塩酸ガスを吸着させる と同様の変化 が起るはずで ある。密閉容 器中で微粒子 ケイ酸に $30 \%$ 塩酸上で塩酸 ガスを吸着さ せ, 試料を $800^{\circ} \mathrm{C}$ に抹い て熱処理する と第 6 図の結

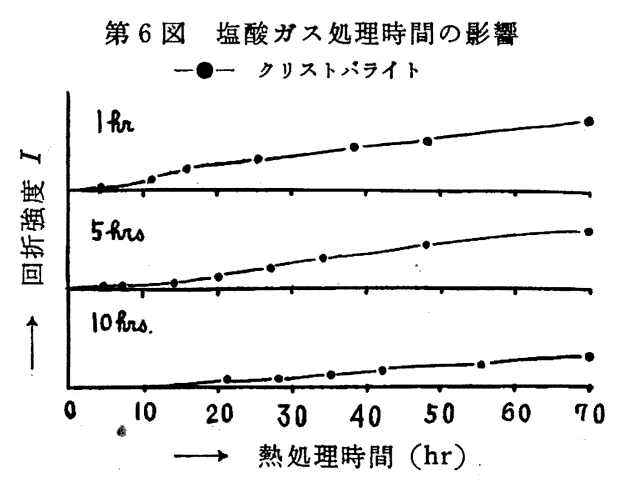

果をえた。

第 6 図の結果は塩酸ガス処理時間の増加とともにクリストバラ イトへの結晶化速度が遅くなるのみで, 石英の生成は認められな い。塩酸の吸着は無定形ヶイ酸生成の原因となるが，石英の生成 の原因とならないことが了解される。

2) 脱水速度 塩酸処理試料 (1 時間漫潰) を本多式熱天科に より 1 分間 に $2^{\circ} \mathrm{C}$ の割 合で温度上 升し, 結合 水の初期脱 水状態を比 較した結果 を第 7 図に 示寸。

既報 ${ }^{3)}$ に おいて微粒 子ケイ酸を 熱天科で脱 水減量曲線 第 7 図塩酸濃度に上る脱水曲線の相違

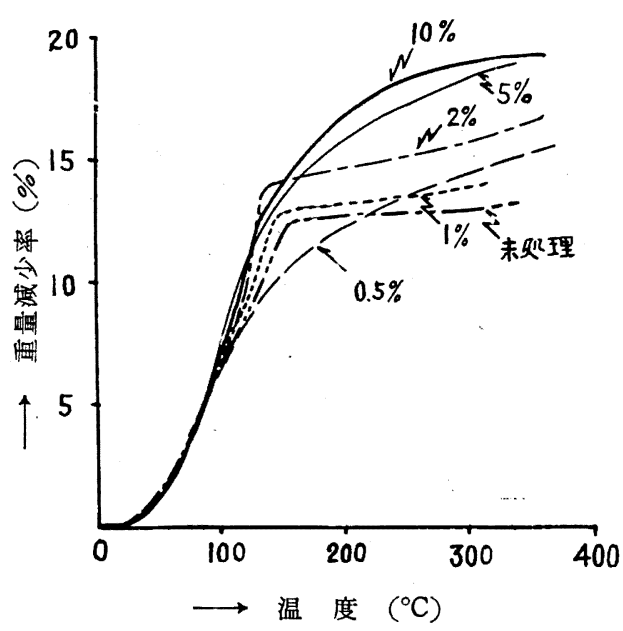

を求めると

$130^{\circ} \mathrm{C}$ 前後に扣いて脱水速度が変化する部分があり, その減量曲 線の変曲点までを吸着水, 以後を結合水と考えた。結合水の初期 脱水速度を第 7 図に見ると熱処理によって結晶質の生成の多いも のは脱水がきわめて遅く, 無定形ケイ酸の多く残存するすのは脱 水速度が速く, そのためケイ酸分子が規則正しく配列せず不規則
な3次元網状構造を つくるものと考えら れる。実際にゴム充 填剤として使用する 場合においても加硫 温度以下で脱水反応 が起ると表面の活性 が减少する。

塩酸処理時間によ る相違を見るため, $2 \%$ 塩酸の場合につ いて同様に観察した 結果を, 第 8 図に示 す。

第 8 図によると処

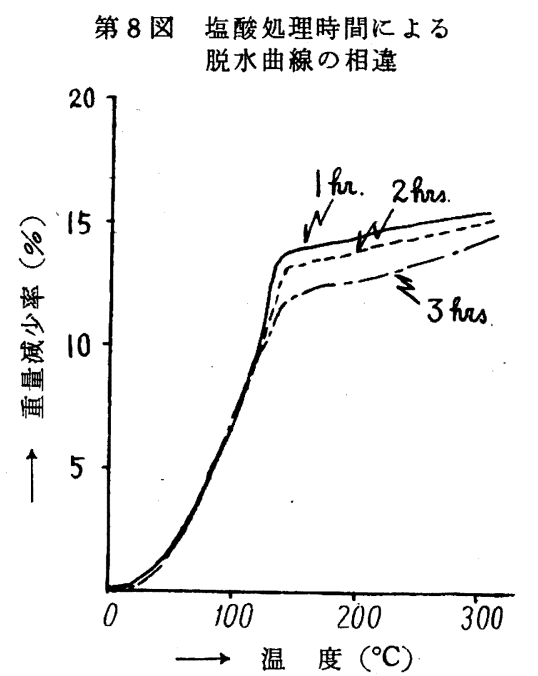
理時間が長くなるとまず吸着水量の低下が見られる。これは吸着 水量が結合水量に対応すると考えると塩酸処理のみで結合水の脱 水反応がある程度進行し, $-\mathrm{OH}$ が減少しているすのと考えられ, 無定形ケイ酸生成の一因をつくっていることが推察される。

3）硫酸処理との比較 硫酸を使用し, 塩酸同様に 1 時間浸漬 した試料を熱 処理すると第 9 図の結果を えた。

硫酸濃度が 希薄な場合は 第 9 図のごと く塩酸と同様 にクリストバ

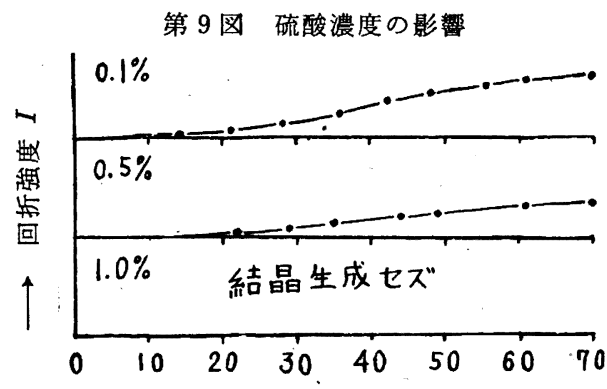
ライトの結晶 $\longrightarrow$ 熱処理時間 $(\mathrm{hr})$

化速度が遅くなって行く。しかし硫酸濃度が $1 \%$ になると結晶 の生成が認められず無定形のまま残る。この熱処理を行った試料 のX線回折図を見ると僅かに無水セッコウの生成が認められ，セ ッコウがケイ酸分子の規則的配列を妨害していることが容易に想 像される。これは微粒子ヶイ酸中に $\mathrm{CaO}$ として $0.2 \%$ の不純 物が存在するため硫酸と反応してセッコウが生成するが, 塩酸の 場合は扣そらく塩化カルシウムとして溶出する事が考えられる。

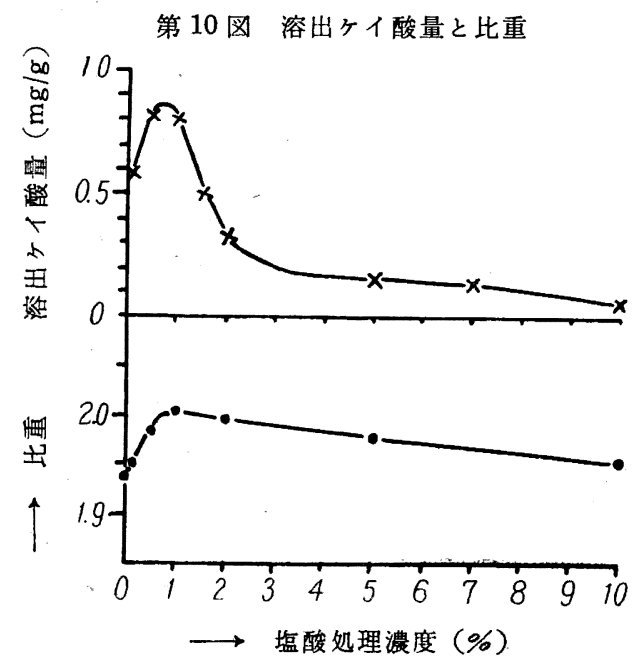


カルシウム化合物の存在は無定形ケイ酸よりクリストバライトヘ の転移を促進するが6)，塩化カルシウムとして溶出されケイ酸分 子の充填密度が大となれば石英の生成率が高くなる現象る了解出 来る。しかしながら塩酸濃度 $1 \%$ で最高の石英生成率を示す原 因は説明されない。

4）溶出ケイ酸 1 時間浸漬処理した種々の濃度の塩酸中に溶 出したケイ酸量を比色法7)によって測定した值ならびに塩酸処理 を行った微粒子ケイ酸を JIS K 5101 の方法により測定した比 重を第 10 図に示した。

微粒子ケイ酸はケイ酸分子の極度の重合を抑制しながらつくら

6) K. Hildu, G. Trömel, Z. anorg. u. allgem. Chem. 215, 333 (1933).

7) 岩畸, 分析化学 2,212 (1953).
れているから1)，低分子量のケイ酸が存在する可能性がある。第 10 因は溶出したケイ酸量が塩酸濃度 0.5 ないし $1 \%$ 付近で最高 を示し，また付記した比重の値と類似の傾向を示している。塩酸 $1 \%$ 付近で低分子量のケイ酸の溶出が最高となり, 熱処理によっ てケイ酸分子が容易に規則的に密に充㙐し，塩酸処理によるイオ ン性の隇少と合せ考えると石英の生成が大となり，塩酸濃度が大 となれば低分子ケイ酸が重合するため溶出が困難となり, 再びら イ酸分子の規則的配列が乱されることが予想される。

(昭和 31 年 11 月, 化学関係学協会連合秋季研究発表大会発 表)

終りに本研究に当り御教示, 御䩒撻を賜わった大阪大学理学部 桐山良一先生ならびに当館高嶋四郎化学部長に感謝の意を表しま す。

\section{エチルアルコールによるクロトンアルデヒドの還元脱水速度†}

（昭 和 31 年 10 月 29 日受 理）

$$
\text { 井上良三・市川明・古川薰* }
$$

\section{はしがき}

エチルアルコール，アセトアルデヒドを原料とするブタジェン 合成反応はアルデヒド相互間のポリ縮合とアルデヒドのアルコー ルによる還元脱水反応の二反応に大別される。そのうちブタジェ ン生成は

$$
\begin{aligned}
& 2 \mathrm{CH}_{8} \cdot \mathrm{CHO} \rightarrow \mathrm{CH}_{3} \mathrm{CH}=\mathrm{CH}-\mathrm{CHO}+\mathrm{H}_{2} \mathrm{O} \\
& \mathrm{CH}_{3} \cdot \mathrm{CH}=\mathrm{CH}-\mathrm{CHO}+\mathrm{C}_{2} \mathrm{H}_{5} \mathrm{OH} \rightarrow \mathrm{C}_{4} \mathrm{H}_{6}+\mathrm{CH}_{3} \cdot \mathrm{CHO}+\mathrm{H}_{2} \mathrm{O}
\end{aligned}
$$

によるものと考えられる。それ故ブタジェンの収率はアセトアル デヒドのクロトンアルデヒドへの縮合と, それのアルコールによ る還元脱水の両速度比によって決定される。しかるにすでに報告 したよ5にアルデヒドのみの気相接触縮合反応はほぼ・random polycondensation として任意の高縮合体を生成する1。ブタジ エンの収率增加のためには，この縮合 2 量体すなわちクロトンア ルデヒドを速かに還元脱水させるものでなければならない。それ 故, アルデヒドの縮合速度とクロトンアルデヒドのアルコールに よる還元脱水速度の関係が重要となってくる。

本報告に扣いては，このような目的で出発物質としてはクロト ンアルデヒドを選び, 両反応速度を分離定量しょうとするるので ある。しかし実際にはこれらの主反応以外にアルコールの分子内 脱水によってェチレンを生成し，あるいは分子間脱水によってエ ーテルを生成する反応があり，さらにクロトンアルデヒドについ てはこれのプロピレンと一酸化炭素への分解, エステルの生成等 の諸反応をともな5。これらはいずれむブタジェン合成の目的の ためには不用な副反応となるものである。

\section{実験方法および関係式}

上述のようにエチルアルコールとクロトンアルデヒドの気相接

\footnotetext{
† 本報告を「アルコールとアセトアルデヒド法によるブタジ エンの合成（第 4 報)」とする，

* 大阪工業技術試験所第 2 部：大阪市大淀区大仁.

1) 井上, 市川, 古川, 高分子化学 14，7月号 (1957).
}

触反応は種々の反応を伴な5ものであるが，本研究の目的からし て, 今もし実験をアルデヒド基量の变化およびブタジェン生成量 の追跡にのみ限って行い, かつ接触反応時間零に外捜することに よって反応の初速度を求めるすのであるとするならば, ここに考 慮すべき反応として次の四つのみが残る。

$$
\begin{aligned}
& 2 \mathrm{~A}_{2} \underset{\mathrm{a}_{2}}{\stackrel{k_{2}}{\longrightarrow}} \mathrm{A}_{4} \\
& \mathrm{~A}_{0}+\mathrm{A}_{2} \stackrel{k_{02}}{\underset{a_{0} a_{2}}{\longrightarrow}} \mathrm{C}_{4}+\mathrm{A}_{1}+\mathrm{H}_{2} \mathrm{O} \\
& \mathrm{A}_{0} \stackrel{\stackrel{k_{0}}{\longrightarrow}}{\stackrel{a_{0}}{\longrightarrow}} \mathrm{A}_{1}+\mathrm{H}_{2} \\
& \mathrm{~A}_{2} \underset{a_{2}}{\stackrel{k_{2}}{\longrightarrow}} \mathrm{CH}_{3} \cdot \mathrm{CH}=\mathrm{CH}_{2}+\mathrm{CO}
\end{aligned}
$$

ただし $\mathrm{A}_{0}$ ：エチルアルコール， $\mathrm{A}_{1}$ ：アセトアルデヒド， $\mathrm{A}_{2}$ : クロトンアルデとド， $\mathrm{A}_{4}$ : オクタトリエナール， $k_{i}, a_{i}:$ それぞ れの反応速度定数扣よび吸着平衡定数。

アルデヒド基の変化は（1)，(3)，(4) 式に関係し，ブタジェン の生成は（2）式にのみ関係する。

実験は酸化タンタル $2 \%$ を吸着させたシリカゲルを用い,こ の触媒上を所定条件で混合ガスを通過させ接触時間零に外插して 新鮮な触媒についての初速度を求めることにする。反応は原料液 滴下様式で行 5が, 触媒の調製その他についてはすでに既報でく わしく述べてあるからここでは省略することとし2), 今の場合こ の触媒を見掛けの容積 $50 \mathrm{cc}$ を使用することのみ記しておく。

さて，今上記の四つの反応に怙いて触媒面上に打ける吸着平衡 はごれを一般式で示すと次のような関係式が成立する。

$$
\begin{aligned}
\theta_{i} & =a_{i}(1-\theta) p_{i} \\
\theta & =\Sigma \theta_{i}=(1-\theta) \Sigma a_{i} p_{i} \\
\theta_{j} & =\frac{a_{j p j}}{1+\sum a_{i} p_{i}}
\end{aligned}
$$

たたし $\theta_{i}: i-\operatorname{mer}$ 分子の吸着された分率， $a_{i}: i$-mer 分子の 吸着平衡定数, $p_{i}: i-\operatorname{mer}$ 分子の分圧（気圧単位） 